\title{
STUDI KRITIK TERHADAP PENENTUAN ARAH KIBLAT DAN AWAL BULAN QAMARIYAH PEMIKIRAN KH. AHMAD DAHLAN
}

\author{
Imroatul Munfaridah \\ IAIN Walisongo Semarang \\ e-mail : farids_girl85@yahoo.com
}

\begin{abstract}
Abstrak
This research tries to reveal and explain the KH. Ahmad Dahlan thoughts about the direction of Qibla and the beginning of the month Qamariyah terms of cosmography or astronomy. And for the authors use the approach of cosmography or astronomy that are characteristic of this research is supported by interviews and documentation to obtain representative data. From this approach can be found in the results, namely: First, KH. Ahmad Dahlan able to create a theory of determining the Qibla direction is using a globe, which was not very advanced technology, with the globe KH. Ahmad Dahlan considered that Qibla direction the city of Yogyakarta in general and in particular the Great Mosque is $24^{\circ}$. And when compared with contemporary software calculation the Qibla is less oblique direction to the right $1^{0} 15^{\prime} 0$ " from the real direction, while the calculation formula of a triangle ball the Qibla is less oblique direction to the right $0^{\circ} 42$ '21.88”. Second, at first KH. Ahmad Dahlan determining the beginning of the month Qamariyah is to follow the teacher's hakiki taqribi K. Dahlan Termas with book Tazkirul Ihwan which tends to geocentric. But once studied with Sheikh Taher Djalaluddin, Dahlan move to the hakiki Tahkiki using reference Matla' al-Sa'id which tends to heliocentric.

Kajian ini berusaha untuk mengungkapkan dan menjelaskan tentang pemikiran KH. Ahmad Dahlan tentang arah kiblat dan awal bulan Qamariyah ditinjau dari ilmu falak atau astronomi. Dan untuk itu penulis menggunakan pendekatan ilmu falak atau astronomi yang merupakan ciri khas dari penelitian ini yang didukung dengan wawancara dan dokumentasi untuk mendapatkan data-data yang representatif. Dari pendekatan tersebut dapat ditemukan hasilnya yaitu; Pertama, KH. Ahmad Dahlan mampu menciptakan teori menentukan arah kiblat yaitu memakai bola dunia, yang saat itu teknologi belum begitu maju, dengan bola dunia itu KH. Ahmad Dahlan berijtihad bahwa arah kiblat kota Yogyakarta pada umumnya dan Masjid Agung pada khususnya adalah $24^{\circ}$. Dan bila dibandingkan dengan perhitungan software kontemporer arah kiblatnya kurang serong ke kanan $1^{0} 15^{\prime} 0$ " (satu derajat lima belas menit nol detik) dari kiblat nyata, sedangkan dari perhitungan rumus segitiga bola arah kiblatnya kurang serong ke kanan $0^{\circ} 42^{\prime} 21.88^{\prime \prime}$. Kedua, pada mulanya KH. Ahmad Dahlan menentukan awal bulan Qamariyah adalah dengan hakiki taqribi mengikuti gurunya K. Dahlan Termas dengan kitab Tazkirul Ihwan yang cenderung geosentris. Tetapi setelah berguru dengan Syekh Taher Djalaluddin, Dahlan berpindah ke hakiki Tahkiki dengan menggunakan referensi Matla'al-Sa'id yang cenderung heliosentris.
\end{abstract}

Kata kunci: KH. Ahmad Dahlan, Kiblat, Awal Bulan Qamariyah

Ilmu falak merupakan salah satu ciri kemajuan peradaban Islam. Namun dalam perjalanannya ilmu falak hanya mengkaji persoalan-persoalan ibadah, seperti arah kiblat, waktu shalat, awal bulan, dan gerhana $^{1}$. Tetapi untuk saat ini ilmu falak mulai memposisikan eksistensinya dengan ilmu astronomi yang

Susiknan Azhari, Ilmu Falak Perjumpaan Khazanah Islam dan Sains Modern (Yogyakarta: Suara Muhammadiyah, 2007), h. 6. akan berjalan bersama-sama untuk perubahan dan perkembangan ilmu pengetahuan.

Di Indonesia pengkajian ilmu falak syar'i (ilmu hisab) juga pernah berkembang pesat. Ulama' yang pertama terkenal sebagai bapak hisab Indonesia adalah Syekh Taher Jalaluddin al-Azhari ${ }^{2}$. Selain

2 Lahir di Koto Tuo Ampat Bukit Tinggi, tanggal 4 Ramadhan 1286 H bertepatan dengan tanggal 7 Desember 1869 M. Ia belajar di Mekkah kurang 
Syekh Taher Jalaluddin pada masa itu juga ada tokohtokoh hisab yang sangat berpengaruh seperti Syekh Ahmad Khatib Minangkabau ${ }^{3}$, Ahmad Rifa'i, dan KH. Shaleh Darat ${ }^{4}$. Di lingkungan Muhammadiyah, kajian ilmu falak syar'i dipelopori oleh Ahmad Dahlan. Sepeninggal beliau, para ulama' Muhammadiyah terus mengembangkan tradisi kefalakan sehingga muncul beberapa ulama' yang memiliki keahlian di bidang ini. Diantaranya adalah KH. Ahmad Badawi ${ }^{5}$ (1902 - 1969), Sa'adoeddin Djambek ${ }^{6}(1911$ - 1977) yang banyak membawa pembaharuan di Indonesia, dan KH. Wardan Diponingrat ${ }^{7}(1911$ - 1991) yang mempelopori hisab hakiki wujudul hilal yang hingga kini dipakai dalam Muhammadiyah untuk penentuan bulan Qamariyah. Sesudah mereka ini lahir pula ahli falak pelanjut tokoh-tokoh di atas, yaitu H.M. Bidran

lebih 14 tahun dibawah bimbingan Ahmad Khatib, kemudian ia melanjutkan ke Universitas Al-Azhar Kairo Mesir, dan belajar di sana selama 4 tahun dengan mendapat keahlian (syahadat 'alimiyah) dalam ilmu falak, karena itu namanya sering ditambah dengan Al-Azhari Al-Falaki. lihat Susiknan Azhari, Ensiklopedi Hisab Rukyat (Yogyakarta: Pustaka Pelajar, 2008), h. 205-206.

3 Seorang ahli fikih dan ilmu falak yang dilahirkan di kota Bukittinggi, Sumatra Barat. Menurut Prof. Hamka, Ahmad Khatib lahir tahun 1860 M, sedangkan menurut Dr. Deliar Noer, tahun 1855 M. sepanjang hayatnya dihabiskannya di Mekkah. Adapun karya-karyanya yang terkait dengan ilmu falak adalah al-Jawahir an-Naqiyyah fi A'mal al-Jaibiyyah dan Raudah al-Hisab fi 'Ilm al-Hisab. Lihat Ibid., h. 15-16.

4 Adalah seorang ahli falak dan pengarang jawa yang terkemuka pada akhir abad XIX. Nama lengkapnya adalah KH. M. Shaleh bin Haji Umar alSamarani, dilahirkan di desa Kedung Cumpleng Kecamatan Mayong Kabupaten Jepara Jawa Tengah pada tahun $1820 \mathrm{M} / 1236 \mathrm{H}$ dan meninggal dunia pada hari jum'at legi 28 Ramadhan $1322 \mathrm{H}$ bertepatan dengan 18 Desember 1903 M. Berdasarkan hasil penelitian Muchoyyar HS keahlian K.H.M. Shaleh Darat dalam bidang ilmu falak diperoleh dari KH. Abu Abdillah Muhammad Ibn Hadi al-Ba'uni seorang mufti di Semarang. Keduanya pernah memperdalam ilmu falak di bawah bimbingan KH. Muhammad Nur Sepaton Semarang. Menurut data sejarah KH. M. Shaleh Darat merupakan salah seorang guru falak KH. Ahmad Dahlan. Lihat Ibid., h. 192.

5 Ahmad Badawi lahir pada tahun 1902, ayahnya bernama Muhammad Fakih (KH. Habiburrahman) bin Kiai Resosetiko, sedangkan ibunya bernama Nyai Hj. Siti Habibah (Nyai H.M. Fakih), beliau merupakan adik kandung dari K.H Ahmad Dahlan. Karya beliau di bidang ilmu falak salah satunya adalah Djadwal Waktu Shalat untuk selama-lamanya. Lihat Yunan Yusuf dkk, Ensiklopedi Muhammadiyah (Jakarta: Raja Grafindo Persada, 2005), h. 43-47.

6 Sa'adoeddin Djambek lahir pada tanggal 24 Maret tahun 1911 di Bukittinggi, Sumatera Barat. Ayahnya bernama Syaikh Muhammad Djamil Djambek merupakan salah seorang ulama besar dan ahli falak dari Minangkabau. Sa'adoeddin mulai tertarik mempelajari ilmu falak (ilmu hisab) yang ia pelajari langsung dari ayahandanya sendiri yang merupakan ulama ahli falak. Ia juga belajar ilmu falak dari Syaikh Taher Jalaluddin, ahli falak dari Malaysia, yang mengajar di al-jami'ah al-Islamiyah Padang Tahun 1939. (PKES Interaktif, "Sa'doeddin Djambek Ahli Falak Muhammadiyah", internet website: http://pkesinteraktif.com/edukasi/sosok/1355-saadoeddindjambek-ahli-falak-muhammadiyah-.html, diakses tanggal 10 Januari 2011).

7 Adalah Ahli falak, nama kecilnya adalah Muhammad Wardan, dilahirkan pada tanggal 19 Mei 1911 M bertepatan dengan tanggal 20 Jumadil Ula 1329 H di Kauman, Yogyakarta dan meninggal dunia pada tanggal 3 Februari 1991 M/ 19 Rajab 1411 H. Karena kepiawaiannya di bidang ilmu Falak, sejak tahun 1973 hingga wafatnya dipercaya sebagai anggota Badan Hisab Rukyat Departemen Agama RI.. (Direktorat Jenderal Bimbingan Masyarakat Islam Kementerian Agama Republik Indonesia, "Wardan Diponingrat Kanjeng Yang Ahli Falak", internet website: http://bimasislam. kemenag.go.id/index.php?option=com_content\&view=article\&id=1135\&c atid=1:berita\&Itemid=63 diakses tanggal 10 Januari 2011).
Hadie $^{8}$ (1925-1994), Ir. H. Basith Wahid ${ }^{9}$ (1925 2008), dan Drs. H. Abdur Rachim ${ }^{10}$ (1935 - 2004). Sesudah mereka ini lahir pula generasi baru ahli falak Muhammadiyah yang aktif di Majlis Tarjih PP Muhammadiyah dan murid dari H. Abdur Rachim, antara lain Drs. Oman Fathurohman, SW, M.Ag. (lahir 1957), Prof. Dr.H. Susiknan Azhari, MA (lahir 1968), dan Drs. H. Sriyatin Shadiq al-Falaky ${ }^{11}$.

Fokus pada penelitianini, sepanjang pengetahuan dan penelusuran penulis ternyata KH.Ahmad Dahlan merupakan salah satu tokoh pemikir dan pembaharu dalam hal ilmu falak, yang meluruskan arah kiblat Masjid Agung Yogyakarta pada tahun 1897 M / 1315 H. Pada saat itu Masjid Agung dan masjid-masjid lainnya, letaknya ke Barat lurus, tidak tepat menuju arah kiblat yang 24 derajat arah Barat Laut. Dengan berbekal pengetahuan ilmu falak atau ilmu hisab yang dipelajari melalui K.H. Dahlan (Semarang), Kyai Termas (Jawa Timur), Kyai Shaleh Darat (Semarang), Syekh Muhammad Jamil Djambek, dan Syekh Ahmad Khatib Minangkabau, Dahlan menghitung kepersisan arah kiblat pada setiap masjid yang melenceng ${ }^{12}$.

Ahmad Dahlan adalah seorang yang memiliki pengetahuan sangat luas. Meskipun usianya baru 20 tahun, ia mulai merintis jalan pembaharuan di kalangan umat Islam. Misalnya, membetulkan arah kiblat shalat pada Masjid yang dipandang tidak tepat arahnya, dengan menyesuaikan perhitungan ilmu falak (ilmu perbintangan) yang dikuasainya. ${ }^{13}$ Langkah ini berawal karena pada masa hidupnya $\mathrm{KH}$. Ahmad Dahlan, masyarakat Islam sedang ditimpa

8 Adalah ahli falak yang dilahirkan di kauman Yogyakarta pada tahun $1925 \mathrm{M}$ dan meninggal dunia pada tahun 1994 M. menurut data sejarah ia termasuk pendiri lembaga Astronomi Himpunan Mahasiswa Islam (LAHMI). Berkat keilmuannya di bidang falak ia diberi amanat menjadi anggota bagian Hisab Majlis Tarjih Pimpinan Pusat Muhammadiyah dan Anggota Badan Hisab dan Rukyat Departemen Agama RI mewakili Muhammadiyah (Azhari, 2008: 45-46).

9 Adalah salah seorang tokoh falak, lahir di Yogyakarta pada tanggal 12 Desember $1925 \mathrm{M}$ dan meninggal dunia pada tanggal 21 Januari $2008 \mathrm{M}$. Keahliannya dalam bidang ilmu falak diperoleh dari guru-gurunya, yaitu: KH. Syamsun Jombang, KH. Siraadj Dahlan (Putra Ahmad Dahlan), dan KH. Muhammad Wardan Diponingrat (Azhari, 2008: 44).

10 Adalah ahli tafsir dan falak yang lahir di Panarukan pada tanggal 3 Februari 1935 M. karirnya sebagai pendidik dimulai sejak ia sebagai mahasiswa doktoral, dipercaya sebagai asisten H. Sa'adoeddin Djambek dalam mata kuliah ilmu falak, sejak tahun 1965 M. ia diangkat sebagai ketua Lembaga Hisab dan Rukyah sejak tahun 1972 M. Setelah H. Sa'adoeddin Djambek meninggal, ia diserahi tugas gurunya sebagai wakil ketua Badan Hisab Rukyah Departemen Agama Pusat. Lihat Abdur Rachim, Ilmu Falak (Yogyakarta: Liberty, 1983), h. Bodata.

11 Pimpinan Pusat Muhammadiyah Majlis Tarjih, Pedoman Hisab Muhammadiyah (Yogyakarta: Suara Muhammadiyah, 2009), h. 11-12.

12 Bimas Depag, 2007, internet website: http://bimasislam.kemenag.go.id/ index.php?option $=$ com content $\&$ view $=$ article $\&$ id $=1124 \&$ catid $=1$ :berita $\&$ I temid $=50$, diakses tanggal 28 November 2010 .

13 Pujangga, 2010 , "Benahi Arah Kiblat", internet website: http://pujanggalampung.blogspot.com/2010/04/kh-ahmad-dahlan-tokoh-pembaru-islamdi.html, diakses tanggal 26 November 2010. 
oleh berbagai macam kritis. Umat Islam telah lupa pada tuntunan agama yang berdasar atas Qur'an dan Hadist. Mereka telah berbuat bid'ah, khufarat, dan syirik. Hal inilah yang menyebabkan mereka jauh dari tuntunan agama yang sebenarnya ${ }^{14}$.

Di awal kiprahnya, KH. Ahmad Dahlan kerap mendapat rintangan, bahkan dicap hendak mendirikan agamabaru. Namun keteguhan sikapnya menyebabkan ia dicatat sebagai pelopor pembetulan arah kiblat dari semua surau dan Masjid di Indonesia. Tak cuma itu reputasi yang ditorehkannya. Berdasarkan pengetahuan ilmu falak dan hisab yang dimilikinya, Dahlan melalui Muhammadiyah, mendasarkan awal puasa dan Syawal dengan Hisab atau perhitungan. Namun sayangnya, Ahmad Dahlan sama sekali tidak pernah menorehkan gagasan pembaharuannya dalam warisan tertulis, tetapi lebih pada karya dan aksi sosial nyata.

Sehingga bisa ditarik kesimpulan bahwa beliau mempunyai pemikiran yang langsung pada action daripada menulis pemikirannya menjadi sebuah buku, seperti pada keterlibatannya dalam bidang ilmu falak yang mana beliau cukup berani menentukan dan membenarkan arah kiblat Masjid besar Keraton Yogyakarta dengan berdasarkan keilmuan falaknya begitu juga penentuan awal bulan Qamariyah. ${ }^{15}$

Tulisan ini merupakan bagian dari hasil penelitian yang penulis lakukan pada bulan Desember 2010 hingga bulan Maret 2011. Oleh karena itu fokus kajiannya tentang Penentuan Arah Kiblat dan Awal Bulan Qamariyah menurut Pemikiran KH. Ahmad Dahlan, maka publikasi mengenai hasil kajian ini diharapkan menarik dan mampu memberikan kontribusi dan sumbangan pemikiran khususnya tentang tokoh-tokoh ilmu falak yang ada di Indonesia.

Tujuan kajian ini adalah untuk mengetahui dan menjelaskan penentuan arah kiblat menurut pemikiran ilmu falak KH. Ahmad Dahlan, serta untuk mengetahui dan menjelaskan penentuan awal bulan Qamariyah menurut pemikiran ilmu falak KH Ahmad

14 Junus Salam, KH. Ahmad Dahlan Amal dan Perjuangannya (Tangerang: al-Wasat Publishing House, 2009), h. 93.

15 Berdasarkan wawancara dengan bapak Ahmad Adarby Darban (seorang sejarahwan dan masih keluarga dengan KH. Ahmad Dahlan dan beliau salah satu cucu dari Muhammad Wardan), pada hari jum'at tanggal 24 Desember 2010 pada pukul 10.00 - 11.00 WIB. Beliau menjelaskan bahwa KH. Ahmad Dahlan dalam menentukan arah kiblat dulu ketika belajar falak dari Timur Tengah beliau membawa globe, dengan globe pula yang dipadu dengan ilmu geografi beliau menetapkan bahwa arah kiblat masjid di Yogyakarta khususnya serong ke barat laut $24^{\circ}$. Dan tentang awal bulan bulan Qamariyah beliau juga menjelaskan bahwa KH.Ahmad Dahlan dalam menetapkan awal bulan Qamariyah pertama kali menggunakan metode rukyah, tetapi setelah belajar dan mengetahui ilmu falak beliau menggunakan hisab yang mana biasa disebut dengan rukyah bil 'ilmi. Akan tetapi apabila rukyah mendahului hisab, maka rukyah yang digunakan lebih dahulu.
Dahlan ditinjau dari ilmu falak.

Penelitian ini dilakukan dengan menggunakan metode kualitatif. Pengumpulan data dilakukan menggunakan teknik wawancara mendalam, studi kepustakaan dan dokumentasi. Untuk memperoleh data yang akurat di lapangan, dilakukan pengumpulan data secara triangulasi. Data yang berhasil dikumpulkan diolah melalui tahap editing, klasifikasi, komparasi dan interpretasi/ penafsiran untuk memperoleh pemahaman baru.

Pendekatan penelitian yang penulis lakukan adalah tentang pemikiran tokoh, khususnya menganalisa sekaligus melakukan studi kritik terhadap pemikiran KH. Ahmad Dahlan, pemikiran beliau adalah melakukan pembaharuan dan menentukan konsep arah kiblat dan penentuan awal bulan Qamariyah, dengan latar belakang pendidikan yang secara simultan mempengaruhi terhadap proses pembaharuan dan pemikirannya khususnya pada ilmu falak apakah sesuai dengan teori-teori keilmuan falak (astronomi). Oleh sebab itu pendekatan yang dipakai dalam penelitian ini adalah pendekatan Astronomis.

\section{Arah Kiblat dan Awal Bulan Qamariyah}

Pada hakikatnya, arah menghadap kiblat dapat ditentukan dari setiap titik atau tempat di permukaan bumi dengan melakukan perhitungan dan pengukuran. Arah kiblat yang selama ini dipakai dalam astronomi adalah besar sudut suatu tempat yang dihitung sepanjang lingkaran kaki langit dari titik utara hingga titik perpotongan lingkaran vertikal yang menuju tempat itu dengan lingkaran kaki langit searah dengan arah jarum jam ${ }^{16}$.

Sejak abad ke3 dan ke-9, astronom muslim bekerja dengan tradisinya menggunakan metode astronomi klasik yang dirancang untuk menghitung Ka'bah untuk tempat di manapun di muka bumi ini berasal dari data geografis yang telah tersedia. Bagi mereka, Ka'bah itu adalah arah yang melalui lingkaran besar $^{17}$ yang dihubungkan dengan lokasi menuju ke Makkah, diukur sebagai sudut ke suatu tempat. Meridian penentuan Ka'bah sesuai dengan definisi ini adalah bukan masalah yang biasa tentang geografi matematika, dimana solusinya melibatkan penerapan rumus trigonometri yang rumit atau konstruksi geometris ${ }^{18}$.

\footnotetext{
16 Departemen Agama, Almanak Hisab Rukyat (Jakarta: Proyek Pembinan Badan Peradilan Agama Islam, 1981), h. 224.

17 Lingkaran besar yaitu lingkaran pada permukaan bola langit yang dibuat melalui pasangan titik-titik pada permukaan bola langit yang berlawanan dan bertitik pusat pada pusat bola langit. Lihat Azhari, ensiklopedi..., h. 132.

18 David King, Astronomy in the Service of Islam (USA: Variorum, 1993), h. 4-5.
} 
Arah kota Makkah yang terdapat Ka'bah (sebagai kiblat kaum muslimin) dapat diketahui dari setiap titik yang berada di permukaan bola bumi, maka untuk menentukan arah kiblat dapat dilakukan dengan menggunakan Ilmu Ukur Segitiga Bola (Spherical Trigonometri). Penghitungan dan pengukuran dilakukan dengan derajat sudut dari titik kutub utara, dengan menggunakan alat bantu mesin hitung atau kalkulator. Atau dapat ditentukan dengan cara mengetahui jam bayang-bayang kiblat setiap hari di permukaan ini ${ }^{19}$.

Untuk perhitungan arah kiblat, ada 3 buah titik yang harus dibuat, yaitu: (1) Titik A, diletakkan di lokasi tempat yang akan ditentukan arah kiblatnya. (2) Titik B, diletakkan di Ka'bah (Makkah). (3) Titik $\mathrm{C}$, diletakkan di titik kutub utara.

Titik B dan titik $\mathrm{C}$ adalah dua titik yang tetap (tidak berubah-ubah), karena titik B tepat di Ka'bah (Makkah) dan titik C tepat di kutub utara (titik sumbu), sedangkan titik A senantiasa berubah, mungkin berada di sebelah utara equator dan mungkin pula berada di sebelah selatannya, tergantung pada tempat yang akan ditentukan arah kiblatnya. Bila ketiga titik tersebut dihubungkan dengan garis lengkung pada lingkaran besar, maka terjadilah segitiga bola $\mathrm{ABC}$, seperti gambar di bawah ini. Titik A adalah posisi lokasi tempat/ kota, titik B adalah posisi Ka'bah (Mekah), dan titik $\mathrm{C}$ adalah kutub utara/ titik sumbu.

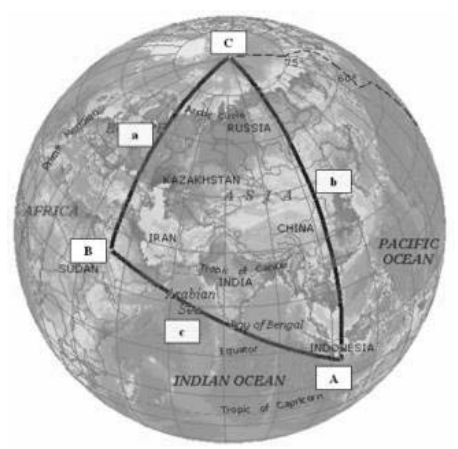

Gambar 1

Secara historis cara penentuan arah kiblat di Indonesia mengalami perkembangan sesuai dengan kualitas dan kapasitas intelektual di kalangan kaum muslimin. Perkembangan penentuan arah kiblat ini dapat dilihat dari perubahan besar di masa $\mathrm{KH}$. Ahmad Dahlan dan Muhammad Arsyad al-Banjari ${ }^{20}$.

19 Sriyatin Shadiq al-Falaky, Metode Perhitungan Arah Kiblat (Surabaya: Balai Diklat Kantor Wilayah Departemen Agama, 2006), h. 2.

20 Adalah seorang ahli falak, yang juga dikenal dengan nama Tuanta Salamakka dan Datuk Kalampayan, lahir di Desa Lok Gabang, Martapura, Kalimantan Selatan pada 15 Safar 1122 H, bertepatan dengan 19 Maret 1710 M. Dalam per jalanan pulang dari Tanah Suci ke Indonesia, Syekh Arsyad tidak langsung pulang ke Banjarmasin, dia singgah dulu bersama sahabatnya
Selanjutnya dalam penentuan arah kiblat Dr. Ing. Khafidz menyebutkan bahwa arah kiblat titik A dapat dihitung dengan rumus sebagai berikut:

Arah kiblat:

$$
\operatorname{cotg} B=\frac{\operatorname{cotg} b \sin a}{\sin C}-\cos a \operatorname{cotg} C
$$

Sedangkan perihal penentuan awal bulan hingga saat ini masih terdapat perbedaan di kalangan ulama' fiqih maupun otoritas pemerintahan negeri-negeri Muslim antara rukyah al-hilal (yang oleh sebagian kalangan muslim dipandang wajib) dan penggunaan hisab, baik hisab imkan al-Rukyah (dengan menggunakan visibilitas hilal maupun yang lainnya) maupun hisab bukan imkan al-Rukyah (seperti hisab wujudul hilal).

Secara garis besarnya ada dua sistem yang dipegang para ahli hisab dalam menentukan awal bulan Qamariyah, yaitu: Sistem Ijtima' dan Sistem Posisi Hilal.

Kelompok yang berpegang pada sistem ijtima' menetapkan bahwa jika ijtima' terjadi sebelum saat Matahari terbenam, maka sejak matahari terbenam itulah awal bulan baru sudah mulai masuk. Sedangkan kelompok yang berpegang pada posisi hilal menetapkan jika pada saat matahari terbenam posisi hilal sudah berada di atas ufuk, maka sejak matahari terbenam itulah bulan baru mulai dihitung.

Para ahli hisab yang berpegang pada posisi hilal, terbagi pada tiga kelompok, yaitu: Pertama, Kelompok yang berpegang pada ufuk hakiki/ True Horizon. Awal bulan Qamariyah berdasarkan posisi hilal di ufuk hakiki, yaitu bidang datar yang melalui titik pusat bumi dan tegak lurus terhadap garis vertikal si pengamat. Kelompok ini tidak mempermasalahkan koreksi-koreksi dengan tinggi tempat pengamat, parallaks (Ikhtilaful manzar) atau beda lihat, refraksi atau pembiasan sinar, dan jejari bulan. Dengan menganut kelompok ini berarti akan tercapai kondisi hilal global, minimal untuk separuh belahan bumi, dan ini

\footnotetext{
Syekh 'Abd Al-Wahab Bugis beberapa bulan di rumah sahabatnya, Syekh 'Abd Al-Rahman Al-Masri di Jakarta. Selama di Jakarta, Syekh Arsyad sempat membetulkan arah kiblat masjid-masjid yang menurut pelajaran ilmu falak yang telah dipelajari dan menurut keyakinannya tidak tepat. Masjid-masjid tersebut di antaranya adalah: Masjid Jembatan Lima, Masjid Luar Batang, dan Masjid Pekojan. Dalam mihrab Masjid Jembatan Lima yang telah dibetulkan arah kiblatnya tersebut terdapat prasasti Arab yang menunjukkan bahwa kiblat masjid ini telah diputar ke kanan sekitar 25 derajat oleh Al-Banjari (Muhammad Arsyad) pada tanggal 4 Safar 1186 H/7 Mei 1772 M (Dewan Redaksi Ensiklopedi Islam, 1994). Dalam masalah ini Syekh Arsyad berpendapat bahwa arah kiblat harus diperbaiki apabila arah tersebut terbukti tidak benar (Biografi Syekh Muhammad Arsyad alBanjari, internet website: http://pp-albanjari.com/index.php?option=com c ontent\&view=article\&id=19\&Itemid=27, diakses tanggal 8 Januari 2011).
} 
tidak realistis karena kenyataanya, kecepatan sudut perjalanan bulan hanya sekitar $33^{\prime} / \mathrm{jam}$ yang jauh lebih lambat dibandingkan dengan kecepatan sudut rotasi bumi yang $15 \%$ jam. Dari perbedaan kecepatan sudut yang sangat besar ini saja jelas tidak mungkin memberlakukan kriteria global. Itulah sebabnya umat Islam selalu menggunakan prinsip Ikhtilaf al-Matla atau hilal lokal ${ }^{21}$.

Kedua, Kelompok yang berpegang pada ufuk mar'i / visible horizon. Kelompok ini menetapkan bahwa awal bulan Qamariyah mulai dihitung jika pada saat matahari terbenam posisi piringan bulan sudah lebih timur dari posisi piringan matahari. Yang menjadi ukuran arah timur dalam hal ini adalah ufuk mar' $i$. Jadi artinya menurut kelompok ini, jika pada saat matahari terbenam tinggi lipat piringan atas hilal sudah berada diatas ufuk mar' $i$, maka sejak itu bulan baru sudah mulai dihitung ${ }^{22}$.

Ufuk mar'i adalah ufuk yang terlihat oleh mata si peninjau. Bedanya ufuk mar' $i$ dengan ufuk hakiki adalah adalah seharga nilai kerendahan ufuk yang diakibatkan oleh ketinggian tempat mata si peninjau. Dalam praktek perhitungannya, kelompok ini memberikan koreksi-koreksi terhadap tinggi hilal menurut perhitungan kelompok pertama. Koreksi-koreksi tersebut adalah; beda lihat (parralaks) dikurangkan, semidiameter ditambahkan, refraksi (pembiasan) ditambahkan, kerendahan ufuk ditambahkan.

Ketiga, Kelompok yang berpegang kepada imkan al-Rukyat. Kelompok ini mengemukakan bahwa untuk masuknya awal bulan baru, posisi hilal pada saat matahari terbenam harus berada pada ketinggian tertentu sehingga memungkinkan untuk dapat dirukyah.

Kriteria imkan al-Rukyat sebenarnya adalah titik temu antara semua pratisi hisab-rukyat di Indonesia. Kriteria imkan al-Rukyat dibuat dari perpaduan data rukyat dan data hisab. Walaupun kriteria imkan alRukyat MABIMS $^{23}$ yang disepakati di Indonesia itu lebih rendah dari kriteria Internasional, sebagai langkah awal itu sudah cukup baik. Kriteria itu harus terus disempurnakan. Salah satu penyempurnaan di-

21 Tono Saksono, Mengkompromikan Rukyat dan Hisab (Jakarta: Amythas Publicita, 2007), h. 147

22 Departemen Agama RI, Almanak Hisab Rukyat (Jakarta: Kementerian Agama, 2010), h. 157.

23 Kriteria imkanur rukyah yang digunakan Indonesia dan disepakati juga pada 1992 oleh negara-negara dalam lingkup MABIMS (Menteri-menteri Agama Brunei Darussalam, Indonesia, Malasyia dan Singapura) dalam penetapan awal bulan Ramadhan, Syawal dan Dzulhijjah adalah sebagai berikut; tinggi bulan minimum $2^{0}$, jarak bulan-matahari minimum $3^{0}$ dan umur bulan saat maghrib minimum $8^{0}$. Kriteria itu dibuat berdasarkan pengalaman rukyatul hilal di Indonesia selama puluhan tahun, walaupun secara Internasional mensyaratkan tinggi bulan minimum $4^{0}$ bila jauh dari matahari dan tinggi bulan minimum $10,5^{\circ}$ bila dekat matahari. Lihat Thomas Djamaluddin, Menggagas Fiqih Astronomi (Bandung: Kaki Langit, 2005), h. 82. lakukan LAPAN Bandung yang mengusulkan kriteria imkan al-Rukyat khas Indonesia. Dengan menganalisis ulang data rukyatul hilal 1962-1997 yang di dokumentasikan Departemen Agama RI telah dibuat kriteria baru yang diperbaiki, antara lain tinggi bulan minimum tidak seragam $2^{0}$, tetapi tergantung pada beda azimutnya. Untuk beda azimut bulan-matahari $0^{0}$, perlu ketinggian lebih dari $8^{024}$.

\section{Sketsa Biografi KH. Ahmad Dahlan}

KH. Ahmad Dahlan lahir di Kampung Kauman ${ }^{25}$ pada tahun 1968 dan wafat pada tanggal 7 Rajab 1340 $\mathrm{H}$ bertepatan dengan tanggal 23 Februari tahun $1923^{26}$. Ia adalah putra keempat dari tujuh bersaudara (semua saudaranya perempuan, kecuali adik bungsunya) dari seorang ayah yang bernama KH. Abu Bakar bin Kiai Sulaiman adalah seorang ulama' dan Khatib terkemuka di Masjid Besar Kasultanan Yogyakarta pada masa itu, dan seorang ibu yang bernama Siti Aminah putri Ibrahim yang juga menjabat penghulu Kasultanan Yogyakarta. KH. Ahmad Dahlan semasa kecil dikenal dengan nama Muhammad Darwis ${ }^{27}$.

KH. Ahmad Dahlan tidak pernah menjalani pendidikan formal dengan memasuki sekolah tertentu. Namun ia menguasai beragam ilmu yang diperoleh dari belajar sendiri (otodidak), berguru kepada ulama' atau seorang ahli, dengan membaca buku-buku atau kitab-kitab. Beberapa ilmu yang dikuasai atau pernah dipelajari adalah ilmu-ilmu; Nahwu (tata bahasa Arab), Fiqih, Falak (perbintangan), Hadits, Qiroatul Qur'an, Pengobatan dan Racun, Filsafat dan Tasawuf $^{28}$. Pada tahun 1890, saat berusia 22 tahun, KH. Ahmad Dahlan menunaikan ibadah haji. Ketika melaksanakan rukun Islam kelima inilah ia mengganti namanya dari Ahmad Darwis menjadi Ahmad

24 Djamaluddin, Hisab Rukyat di Indonesia Serta Permasalahannya (Jakarta: Badan Meteorologi Klimatologi dan Fisika, 2010), h. 157.

25 Kauman adalah nama sebuah kampung di Kotamadya Yogyakarta yang mempunyai ciri-ciri khusus. Masyarakat Kauman merupakat masyarakat yang anggotanya mempunyai pertalian darah. Masyarakat yang demikian ini terjadi dari keluarga-keluarga. Antar keluarga itu kemudian terjadi pertalian darah. Hubungan pertalian darah antar keluarga yang terkumpul pada suatu tempat tertentu, kemudian membentuk masyarakat yang mempunyai karakteristik tersendiri. Kauman adalah kampung yang mempunyai rangkaian dengan Keraton Yogyakarta. Lahirnya Kampung Kauman dimulai dengan adanya penempatan abdi dalem pamethakan, yang bertugas dalam bidang keagamaan, khususnya urusan kemasjidan, disebuah lokasi khusus. Beberapa abdi dalem yang mengurus masjid Agung Yogyakarta diberi tempat oleh sultan di sekitar masjid. Beberapa keluarga abdi dalem itu kemudian membentuk masyarakat yang disebut dengan masyarakat Kauman. Lihat Ahmad Adaby Darban Sejarah Kauman Menguak Identitas Kampung Mu_ hammadiyah (Yogyakarta: Suara Muhammadiyah, 2010), h. 1-2.

26 Djarnawi Hadikusuma, Matahari-matahari Muhammadiyah (Yogyakarta: Suara Muhammadiyah, 2010), h. 12.

27 Hery Sucipto, KH. Ahmad Dahlan; Sang Pencerah, Pendidik dan Pendidri (Jakarta: Best Media Utama, 2010), h. 49.

28 Munir Mulkhan, Pesan dan Kisah Kiai Ahmad Dahlan dalam Hikmah Muhammadiyah (Yogyakarta: Suara Muhammadiyah, 2010), h. 7. 
Dahlan. Tak ada sumber yang menyebutkan mengapa ia mengganti nama dan kenapa ia memilih nama itu. Yang jelas, kepergian Ahmad Dahlan melaksanakan ibadah haji itu telah membuka matanya bahwa bila ingin mendalami ilmu agama, maka di tanah suci itulah tempatnya ${ }^{29}$.

Guru-guru KH. Ahmad Dahlan di tanah jawa adalah Kiai Muhammad Nur, kakak iparnya sendiri, Kiai H. Said, Kiai Mukhsin, Kiai Abdul Hamid di Lempunyangan serta R. Ng. Sosrosugondo (ayah Ir. Suratin) dan R. Wedana Dwijosewoyo. Dalam ilmu hadits mengaji kepada Kiai Mahfudh dan Syekh Khayat. Dalam hal ilmu falak, guru-gurunya ialah Kiai H. Dahlan Semarang, putranya Kiai Termas menantunya Kiai Saleh Darat Semarang, dan Syekh M Jamil DJambek ${ }^{30}$ dari Bukit Tinggi. Sehingga beliau kemudian sebagai seorang ulama', juga dikenal sebagai seorang ahli ilmu falak. Perihal ditentang soal kiblat, KH. Ahmad Dahlan pernah mengajukan persesuaian (kecocokan) dengan Sayid Usman yang tersohor di Jakarta ${ }^{31}$.

Pendidikan yang dilaluinya adalah pendidikan model pondok pesantren, baik di dalam maupun di luar negeri dan sama sekali tidak mengenal pendidikan formal model Barat. Namun semua itu tidak mengurangi bobot beliau sebagai seorang yang alim. Bahkan beliau dikenal secara luas sebagai seorang ulama' sekaligus sebagai cendekiawan yang memiliki wawasan berpikir yang mendalam lagi luas, menjangkau jauh ke masa depan. Kedua predikat yang disandang oleh KH. Ahmad Dahlan ini dibuktikan secara konkrit dalam bentuk dibangunnya sebuah persyarikatan yang bercirikan sebagai gerakan pembaharuan dengan dua sasaran utama, yaitu gerakan pembaharuan dalam bidang pemikiran dengan titik tumpu pemurnian (purifikasi) pemahaman keagamaan, serta pembaharuan (reformasi) dalam bidang sosial pendidikan ${ }^{32}$.

\section{Epistemologi Arah Kiblat KH. Ahmad Dahlan}

Diantara gejala-gejala eksistensi manusia yang

29 Nadjamuddin Ramly, Ensiklopedi Tokoh Muhammadiyah Pemikiran dan Kiprah dalam Panggung Sejarah Muhammadiyah (Jakarta: Best Media Utama, 2010), h. 59.

30 Adalah adalah satu dari tiga ulama pelopor pembaruan Islam dari Sumatra Barat di awal abad ke-20, dilahirkan di Bukittinggi, terkenal sebagai ahli ilmu falak terkemuka. Nama Syekh Muhammad Jamil Djambek lebih dikenal dengan sebutan Inyik Syekh Muhammad Jamil Djambek atau Inyik Djambek, dilahirkan dari keluarga bangsawan. Dia juga merupakan keturunan penghulu. Ayahnya bernama Saleh Datuk Maleka, seorang kepala nagari Kurai, sedangkan ibunya berasal dari Sunda (Mas'oed Abidin Abdul Jabbar Blog, 27 Februari 2011).

31 Junus, KH. Ahmad Dahlan Amal ....., h. 59-60.

32 Musthafa Kamal Pasya dan Ahmad Adaby Darban, Muhammadiyah Sebagai Gerakan Islam (Yogyakarta: Pustaka SM, 2009), h. 148. dialami, satu hal yang amat menyolok mata dan amat penting ialah pengetahuan. Sebab ia merefleksikan eksistensinya secara menyeluruh, manusia terpaksa merefleksikan pengetahuannya juga. Bagian filsafat yang dengan sengaja berusaha menjalankan refleksi atas pengetahuan manusia itu disebut "epistemologi" ,atau ajaran tentang pengetahuan ${ }^{33}$.

KH. Ahmad Dahlan membangun sebuah epistemologi tentang ilmu falak hanya dengan praktik tanpa meninggalkan karya tulis, khususnya pada pembetulan arah kiblat di Masjid Agung Keraton Yogyakarta karena pada masa itu di tengah-tengah masyarakat ada sebuah paradigma baru yang memang berbeda dengan masyarakat tradisional, tetapi sebenarnya paradigma yang dibawa oleh KH.Ahmad Dahlan tujuannya adalah untuk meluruskan agama khususnya di bidang ilmu falak yang berhubungan dengan ibadah shalat yaitu tentang arah kiblat.

Memang pada saat itu keadaan umat Islam/ kaum muslimin sungguh amat menyedihkan, karena keadaan umat Islam di Yogyakarta pada umumnya sangat lemah dan jiwanya diliputi hal-hal yang kompleks, dan Islamnya memang sudah sejak lama dicampuri dengan animisme yang sebesar-besarnya. Sehingga animisme itulah yang dipandang amalan Islam dan ditambah takhayul dan khurafat. Hanya shalat 5 waktu dan puasa yang masih merupakan sifat agama Islam yang asli34.

KH. Ahmad Dahlan pada mulanya belajar ilmu falak tradisional kepada KH. Dahlan (Termas) yaitu dengan aliran hakiki taqribi, kemudian beliau pergi ke Makkah dengan tujuan untuk naik haji dan menimba ilmu, kemudian di sana beliau bertemu dengan kyaikyai modern seperti kyai Jamil Djambek. Sehingga KH. Ahmad Dahlan berubah pemikirannya, beliau tidak hanya menghandalkan ilmu falak tradisional. Jadi dalam penentuan arah kiblat menurut KH. Ahmad Dahlan harus menggunakan ilmu yang kontemporer yaitu menggunakan bola dunia (globe).

Guru-guru yang mempengaruhi inteletual $\mathrm{KH}$. Ahmad Dahlan adalah: (a) KH. Dahlan Termas KH. Shaleh Darat, dari kyai Dahlan Termas dan Kyai Shaleh Darat KH. Ahmad Dahlan mendapat pengetahuan tentang rubu' al-Mujayyab. (b) Jamil Djambek ${ }^{35}$, dari Jamil

33 Syukur Epistemologi Islam Skolastik Pengaruhnya pada Pemikiran Islam Modern (Yogyakarta: Pustaka Pelajar, 2007), h. 42.

34 Haji Muhammad Syuja', Islam Berkemajuan (Kisah Perjuangan KH. Ahmad Dahlan dan Muhammadiyah Masa Awal) (Tangerang: al-Wasath, 2009), h. 55.

35 Adalah adalah satu dari tiga ulama pelopor pembaruan Islam dari Sumatra Barat di awal abad ke-20, dilahirkan di Bukittinggi, terkenal sebagai ahli ilmu falak terkemuka. Nama Syekh Muhammad Jamil Djambek lebih dikenal dengan sebutan Inyik Syekh Muhammad Jamil Djambek atau Inyik 
Djambek KH. Ahmad Dahlan mendapatkan ilmu falak dan pengetahuan tentang bola dunia. (c) Ahmad Khatib, dengan Ahmad Khatib KH. Ahmad Dahlan hanya bersama-sama bertemu beliau dalam sebuah diskusi keilmuan tidak belajar langsung tentang ilmu falak, KH. Ahmad Dahlan hanya melakukan dialog ketika beliau naik haji.

\section{Rubu' sebagai alat tradisional ${ }^{36}$}

Rubu'al-Mujayyab atau disebut dengan "kuadran sinus" adalah alat hitung astronomis untuk memecahkan permasalahan segitiga bola dalam astronomi. Beberapa tokoh yang berperan dalam pengembangan Rubu' ini antara lain; al-Khawarizmi (770-840) dan Ibn Shatir (Abad 11). Rubu' al-Mujayyab yang berkembang di Indonesia adalah rubu' al-Mujayyab yang telah dikembangkan ole Ibn Shatir ${ }^{37}$. Ada tiga fungsi utama dari rubu'al-Mujayyab, yaitu:

Pertama, Hal ini dapat digunakan sebagai pengukuran atau pengamatan perangkat. Menggunakan rubu' al-Mujayyab kita dapat mengamati ketinggian objek seperti Matahari, Bulan, planet dan bintang.

Kedua, Hal ini dapat digunakan untuk menentukan posisi Matahari dalam bujur ekliptika dan deklinasi dalam sistem khatulistiwa.

Ketiga, Dapat digunakan sebagai menghitung atau komputasi perangkat. Menggunakan rubu alMujayyab kita bisa memecahkan masalah dasar astronomi bola ${ }^{38}$.

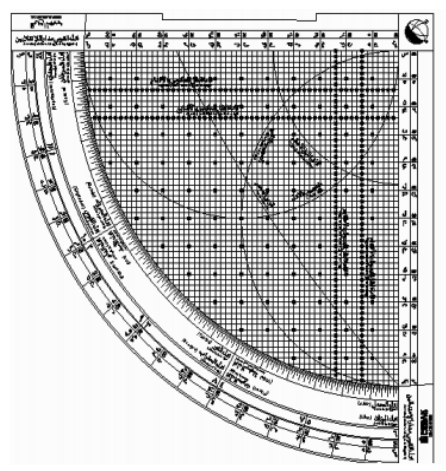

Gambar 2

Dalam kitab Tibyanul Miqat fi ma'rifati alauqat wa al-Qiblat karangan Pondok Pesantren alFalah Ploso Kediri komponen-komponen rubu' al-

Djambek, dilahirkan dari keluarga bangsawan. Mas'oed Abidin Abdul Jabbar Blog, "Inyik Djambek (Syekh Muhammad Djamil Djambek), Mata Rantai Gerakan Pembaharuan Pemikiran Islam di Minangkabau", internet website: http://hmabidin.wordpress.com/2011/02/27/inyik-djambek-syekhmohamad-djamil-djambek-mata-rantai-gerakan-pembaruan-pemikiranislam-di-minangkabau/, diakses tanggal 17 Maret 2011.

36 Berdasarkan wawancara penulis dengan bapak Sriyatin Shadiq al-Falaky, di Sidoarjo pada tanggal 3 Februari 2011).

37 Hendro Setyanto, Rubu'al-Mujayyab,..(tt, 2002), h. 1.

38 Stephenson, W., Astronomical Instruments and Archives (Seoul: Yonsei University Press, 2004), h. 135.
Mujayyab adalah: Qaus : bagian yang melengkung (busur). Jaib (sinus) : satu sisi tempat mengincar yang memuat skala yang mudah terbaca berapa sinus dari tinggi suatu benda langit yang dilihat. Jaib AlTamam : sisi yang memuat skala-skala yang mudah terbaca beberapa cosinus dari tinggi benda tersebut, nilai jaib ini adalah 60 , terhitung dari arah vertikal. Jaib Al-Mabsuth : suatu sudut kemiringan cahaya pada bidang datar yang horizontal dilihat dari ujung bayang-bayang dari benda yang berdiri tegak. Jaib AlMankus : sinus sudut kemiringan cahaya pada bidang datar yang berdiri tegak dilihat dari ujung bayangbayang dari benda yang tegak lurus pada bidang itu. Awwal Al-Qaus : bagian busur yang berimpit dengan sisi jaib al-tamam (permulaan busur). Akhir Al-Qaus : bagian busur yang berimpit dengan sisi jaib. Dari awal qaus hingga akhir qaus dibagi dengan skala $0^{\circ}$ $\mathrm{s} / \mathrm{d} 90^{\circ}$. Hadafah : pada sisi jaib terdapat lubang untuk mengincar (sasaran). Markaz : titik sudut siku-sukunya terdapat lubang kecil untuk tali yang biasanya terbuat dari benang sutera, (sebaiknya tali terbuat dari tali setipistipisnya). Muri : simpulan benang kecil yang terdapat (diikatkan) pada benang tipis yang dapat digeser/digerakkan. Dan Syaqul : pada ujung tali (benang) yang diberi beban yang terbuat dari metal.

Berdasarkan wawancara dengan bapak Sriyatin Shadiq al-Falaky seorang ahli hisab yang merupakan murid dari Abdurrahim, berdasarkan cerita dari guru beliau yang turun-temurun ditarik ke atas sampai pada gurunya yaitu KH.Ahmad Dahlan, menjelaskan bahwa pada masa KH. Ahmad Dahlan sudah menggunakan rubu' tetapi KH. Ahmad Dahlan sudah melompat tinggi dengan bangunan epistemologi bola dunia. Disebabkan karena rubu' yang diajarkan di Indonesia itu mempunyai kelemahan karena hanya mengajarkan daerah Selatan khatulistiwa saja. Sehingga KH. Ahmad Dahlan timbul pemikiran bagaimana kalau menggunakan bola dunia ${ }^{39}$ dalam menentukan arah kiblat untuk setiap tempat berdasarkan letak geografisnya, kemudian timbullah epistemologi bola dunia.

KH. Ahmad Dahlan tidak menggunakan rubu' dalam pembetulan masjid Agung Yogyakarta, sehingga KH. Ahmad Dahlan sering diceritakan di buku-buku dan dari beberapa sumber bahwa pengukurannya menggunakan kompas (yang di dapat dari Belanda), peta dunia, dan bola dunia (globe).

39 Bola dunia atau Globe adalah suatu bentuk tiruan bola bumi yang dibuat dalam skala yang kecil untuk dapat lebih memahami bentuk asli planet bumi. 


\section{Bola Dunia sebagai alat modern ${ }^{40}$}

Setelah KH. Ahmad Dahlan mengetahui bangunan epistemologi tentang bola dunia, beliau menyimpulkan bahwa Yogyakarta atau masjid agung khususnya berada di sebelah selatan khatulistiwa, dan Makkah di utara khatulistiwa. Jika masjid agung Yogyakarta ditarik ke Barat lurus dengan peta datar (dari bola dunia), maka akan menghadap ke Tanzania bukan ke arah Makkah, menurut KH.Ahmad Dahlan hal itu tidak sesuai dengan syar'i karena syar'inya adalah menghadap ke Ka'bah. Oleh karena itu beliau menggunakan bangunan epistemologi bola dunia untuk menentukan arah kiblatnya.

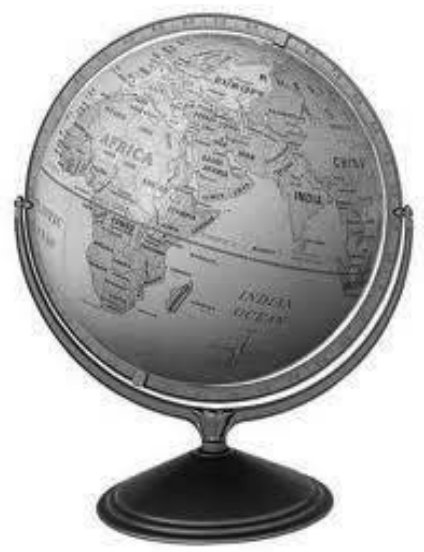

Gambar 3

Zaman dahulu belum ada teknologi seperti zaman sekarang yang sedang berkembang dan terus berkembang dalam menentukan arah kiblat, sehingga KH. Ahmad berijtihad berdasarkan keilmuan falak yang dia miliki bahwa arah kiblat Yogyakarta pada umumnya dan Masjid Agung khususnya adalah $24^{\circ}$. Maka ditulis oleh para ahli sejarah di Indonesia dalam buku-bukunya dari pernyataan-pernyataan termasuk pak Munir Mulkhan yaitu arah kiblat berkisar $24^{\circ}$.

\section{Epistemologi KH. Ahmad Dahlan tentang Awal Bulan Qamariyah}

Epistemologi awal bulan Qamariyah tidak halnya seperti permasalahan arah kiblat yang menimbulkan konflik yang menegang, namun hanya sebatas permasalahan yang terjadi di Keraton bahwa untuk Keraton yang memang masih bagian hidup dari KH. Ahmad Dahlan dalam penentuan Idul Fitrinya menggunakan Aboge. Dalam penentuan awal bulan Qamariyah ini terjadi setelah berdirinya $\mathrm{Mu}-$ hammadiyah.

\footnotetext{
40 Bangunan epistemologi KH. Ahmad Dahlan tentang bola dunia ini berawal dari beliau belajar dari Djamil Djambek. (berdasarkan wawancara penulis dengan bapak Sriyatin Shadiq al-Falaky, di Sidoarjo pada tanggal 3 Februari 2011) .
}

Darban menceritakan dalam menentukan awal bulan Qamariyah KH. Ahmad Dahlan pernah menggunakan rukyat bil 'aini dan menetapkan bahwa satu Syawal terjadi satu hari lebih dahulu dari grebeg syawal, maka untuk melaksanakan shalat Idul Fitri, KH. Ahmad Dahlan dengan diantar oleh kyai penghulu H. Muhammad Kamaluddiningrat menghadap Sultan Hamengku Buwana VII pada malam harinya untuk menyampaikan maksud mengadakan shalat Idul Fitri sehari sebelum Grebeg. Maksud tersebut diterima oleh Sultan, tetapi untuk Grebeg Syawal dilaksanakan seperti biasa, memakai perhitungan Aboge. Di sini, tampaklah keberanian usaha mengubah adat kebiasaan dari KH. Ahmad Dahlan dan K.K. Penghulu Muhammad Kamaluddiningrat.

KH. Ahmad Dahlan kalau diruntut berdasarkan belajar dari gurunya K. Dahlan (Termas) yang menggunakan kitab "Tazkiratul Ihwan"41 yang beraliran geosentrik dan cenderung taqribi, KH. Ahmad Dahlan pada mulanya beraliran hakiki taqribi, kemudian setelah belajar ke Syekh Taher Djalaluddin yang pemikirannya merujuk pada kitab " $M a t\} l a$ ' al- Sa'id" ${ }^{\prime \prime 2}$ yang kitab ini beraliran heliosentrik dan cenderung tahkiki. Kitab "Matla' al-Sa'id" ini dibawa Syekh Taher Djalaluddin dari Timur Tengah dan dikembangkan di Indonesia.

Dari situ timbul sebuah pertanyaan, apakah KH. Ahmad Dahlan memakai taqribi atau tahkiki dalam menentukan awal bulan Qamariyah. Tetapi untuk kesimpulan sementara, maka bisa ditarik sebuah teori bahwa KH. Ahmad Dahlan menggunakan tahkiki, karena berdasarkan buku yang ditulis anaknya (Siraj Dahlan) sekaligus murid beliau yang paling dekat dalam bukunya "Kosmografi Ilmu Falak" rumusrumus yang ditulisnya itu mengacu kepada kitab "Matla' al-Sa'id" yang beraliran hakiki tahkiki. Dan ditarik ke bawah sampai ke murid Siraj Dahlan yaitu Wardan yang menggagas wujudul hilal yang merupakan salah satu metode hakiki dari penentuan awal bulan Qamariyah.

Murid KH. Ahmad Dahlan yang menulis buku khusus tentang ilmu falak adalah putranya sendiri yaitu Siraj Dahlan yang mana murid Siraj Dahlan

\footnotetext{
41 Adalah kitab falak yang ditulis oleh KH. Dahlan al-Simarani (W. 1329 H / 1911 M). kitab ini selesai ditulis pada 28 Jumadil Akhir 1321 H / 21 September 1903 M. sostem perhitungannya menggunakan markaz kota Semarang Jawa Tengah (Azhari, 2008: 207).

42 Adalah kitab yang ditulis oleh Syekh Husain Zaid (Mesir), yang dibawa pulang oleh Syekh Taher Djalaluddin ketika naik haji dan ternyata membawa pengaruh yang cukup besar dalam perkembnagan dan kemajuan ilmu falak di Indonesia. Dan kitab “Matla' al- Sa 'id" ini juga yang menjadi rujukan utama yang digunakan oleh $\mathrm{KH}$. Turaikhan dalam penyusunan almanak Menara Kudus pada tahun 1945 M.
} 
adalah Wardan Diponingrat yang merupakan penggagas teori wujudul hilal yang dilestarikan oleh Muhammadiyah sampai sekarang untuk penentuan awal bulan Qamariyah. Seperti silsilah di bawah ini untuk memperjelas kesinambungan antara guru dan murid $^{43}$

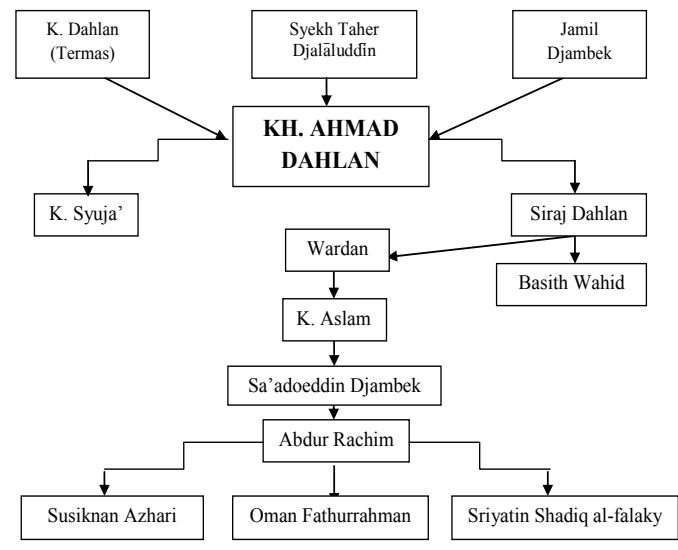

\section{Analisa Terhadap Pemikiran KH. Ahmad Dahlan}

Dalam analisa ini penulis menggunakan pendekatan ilmu falak atau Astronomi. Sebenarnya arah kiblat dari pemikiran KH. Ahmad Dahlan $24^{0}$ jika dihitung dengan bangunan epistemologi trigonometri kontemporer dan dengan software modern maka akan ketemu $25^{\circ}$ arah kiblat Yogyakarta.

Tetapi paradigma dan hasil ijtihad KH. Ahmad Dahlan sudah dianggap bagus, karena sudah ada perubahan dari paradigma menghadap ke Barat sudah berubah $24^{0}$ meskipun terpaut $1^{0} 15^{\prime} 0^{\prime \prime}$ dari perhitungan kontemporer dan hanya terpaut $0^{0} 42^{\prime} 21.88^{\prime \prime}$ dari perhitungan rumus segitiga bola, seperti apa yang penulis lakukan dengan membandingkan perhitungan dari software "Mawaqit" yang data astronomisnya lengkap dan ter-update tiap harinya dibandingkan dengan masa $\mathrm{KH}$. Ahmad dahlan dalam menentukan arah kiblatnya. Seperti di bawah ini:

\section{Gambar 4}

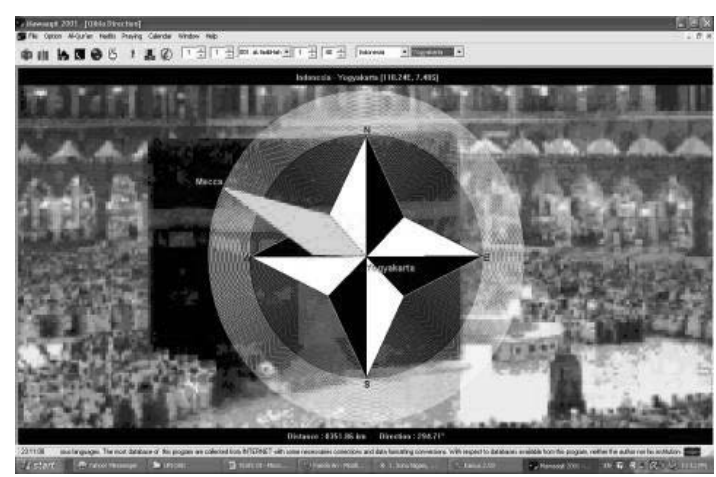

43 Berdasarkan wawancara penulis dengan bapak Sriyatin Shadiq al-Falaky di Sidoarjo pada tanggal 3 Februari 2011.
Berdasarkan perhitungan software ini arah kiblat kota Yogyakarta adalah:

- Dihitung dari arah Utara menuju Timur, Selatan dan Barat $(\mathrm{UTSB})=\mathbf{2 9 4}^{\mathbf{0}} \mathbf{7 1 ^ { \prime }}$

- Dihitung dari arah Utara menuju Barat (U-B) $=64^{0} 49^{\prime} 0$ "'

- Dihitung dari arah Barat menuju Utara (B-U) $=25^{\circ} 11^{\prime} 0^{\prime \prime}$

Sedangkan arah kiblat kota Yogyakarta dengan perhitungan rumus segitiga bola dan perhitungan dibantu dengan kalokulator Casio $f x-4500 P A$ adalah:

$$
\operatorname{cotg} B=\frac{\operatorname{cotg} b \sin a}{\sin C}-\cos a \operatorname{cotg} C
$$

Diketahui

Lintang Tempat kota Yogyakarta $=7^{0} 48^{\prime} \mathrm{LS}$

$$
\begin{array}{ll}
\text { Bujur Tempat kota Yogyakarta } & =110^{\circ} 24^{\prime} \mathrm{BT} \\
\text { Lintang Ka'bah } & =21^{\circ} 25^{\prime} 25^{\prime \prime} \mathrm{LU}
\end{array}
$$$$
\text { Bujur Ka'bah } \quad=39^{\circ} 49^{\prime} 39^{\prime \prime} \text { BT }
$$

$$
\begin{aligned}
& \text { a }=90^{\circ} \text { - Lintang Tempat } \\
& =90^{\circ}-7^{0} 48^{\prime} \mathrm{LS} \\
& =97^{\circ} 48 \\
& \mathrm{~b}=90^{\circ}-\text { Lintang Ka'bah } \\
& =90^{\circ}-21^{0} 25^{\prime} 25^{\prime \prime} \mathrm{LU} \\
& =6^{\circ} 34^{\prime} 35^{\prime \prime} \\
& \text { c = Bujur Tempat }- \text { Bujur Ka'bah } \\
& =110^{\circ} 24^{\prime} \mathrm{BT}-39^{\circ} 49^{\prime} 39^{\prime \prime} \mathrm{BT} \\
& =7^{\circ} 34^{\prime} 21^{\prime \prime}
\end{aligned}
$$

$\rightarrow$ Ditanya

Berapa derajar arah kiblat kota Yogyakarta?

$\rightarrow$ Dijawab

$$
\begin{aligned}
& \operatorname{cotg} B=\frac{\operatorname{cotg} b \sin a}{\sin C}-\cos a \operatorname{cotg} C \\
& \operatorname{Cotg} B=\operatorname{Cotg} 68^{\circ} 34^{\prime} 35^{\prime \prime} \sin 97^{\circ} 48^{\prime}-\cos 97^{\circ} 48^{\prime} \operatorname{cotg} 70^{\circ} 34^{\prime} 21^{\prime \prime} \\
& \operatorname{Sin} 70^{\circ} 34^{\prime} 21^{\prime \prime} \\
& \left.=\mathbf{6 5}^{0} \mathbf{1 7} \mathbf{3 8 . 1 2} \quad \text { (dari U-B }\right) \\
& =\mathbf{2 4}^{0} \mathbf{4 2} 21.88^{\prime \prime} \quad \text { (dari B-U) }
\end{aligned}
$$

Sehinggapenulis bisamenarikkesimpulanbahwa KH. Ahmad Dahlan membangun epistemologi baru tentang penentuan arah kiblat, dimana pemahaman atau keyakinan umat Islam pada zaman dahulu atau tradisional khususnya di lingkungan Yogyakarta beranggapan bahwa kiblat orang Indonesia adalah menghadap ke Barat, yaitu dengan cara menggaris diarahkan ke Barat atau kiblatnya, namun KH. Ahmad Dahlan tidak menerima epistemologi lama itu, sehingga membangun epistemologi baru tentang arah kiblat bahwa karena bumi berbentuk bulat dan tidak datar ber dasarkan bola dunia yang beliau pahami. Maka arah 
kiblat sesungguhnya bukan ke Barat tetapi harus dimiringkan sekian derajat sesuai dengan bola dunia, di manapun tempat di permukaan bumi. Dan perlu diketahui bahwa bangunan epistemologi bola dunia atau globe oleh KH. Ahmad Dahlan merupakan cerminan trigonometri zaman selanjutnya hingga zaman sekarang.

Dan perlu diketahui setelah ditelusuri sejarahnya tentang perkembangan pembetulan arah kiblat di Indonesia ternyata Syekh Arsyad al-Banjari dan Sayyid Usman ${ }^{44}$ yang lebih dulu mempelopori pembetulan arah kiblat yang mana Syekh Arsyad al-Banjari yang pertama kali melakukan pembetulan arah kiblat Masjid Jembatan Lima Betawi (Jakarta) pada tanggal 7 Mei 1772 M, sedangkan Sayyid Usman merupakan generasi yang kedua yang telah mengoreksi arah kiblat Masjid di Palembang, sehingga KH. Ahmad Dahlan bukanlah pelopor/ perintis pertama yang telah disebutkan di beberapa literatur tetapi merupakan generasi yang ketika dan sekaligus pelopor pertama di Muhammadiyah dan yang mempelopori ketika pembetulan arah kiblat antara generasi Syekh Arsyad al-Banjari dan Sayyid Usman terjadi kevakuman yang sangat lama.

Sedangkan dalam peristiwa perdebatan dengan Sultan Hamengku Buwana VII seperti yang telah penulis singgung di depan tentang awal bulan Qamariyah, KH. Ahmad Dahlan mampu menyelesaikan perdebatan tersebut dan memutuskan bahwa jatuhnya tanggal 1 Syawal menurut hisab ilmu falak yaitu ketika peristiwa ini terjadi penulis belum mendapatkan sumber yang kuat mengenai tahun persisnya peristiwa ini. Tetapi menurut Sriyatin Shadiq bahwa peristiwa ini terjadi antara tahun masa jabatan Hamengku Buwana VII tahun 1920M. Sehingga penulis mencoba untuk membandingkan metode taqribi beliau dengan software yang kontemporer, yaitu dengan contoh pada tahun 1920 bahwa hari raya Idul Fitri berdasarkan pemikiran falak KH. Ahmad Dahlan jatuh pada hari Jum'at.

44 Adalah ahli falak yang hidup pada akhir abad ke 19 sampai awal abad ke20. Nama lengkapnya adalah al-Habib Sayyid Usman bin Abd Allah bin Aqil bin Yahya al-'Alawi al-Husaini, dilahirkan di Pakojan, Batavia, pada 17 Rabiul Awal 1238 H / 1822 M dan meninggal dunia pada tahun 1331 H / 18 Januari 1914 M. Dengan keahliannya dalam bidang ilmu falak, dia mengabdikan dirinya untuk mengoreksi arah kiblat beberapa masjid di Palembang. Meskipun kontroversi muncul dari koreksinya atas arah kiblat masjid-masjid tersebut, dia dihormati oleh otoritas Belanda di Batavia. Salah satu karyanya dalam bidang hisab yang kini berada di Perpustakaan Leiden adalah Tahir Aqwa al-adillah fi Tahshili 'Aini al-Qiblah. Lihat Ibid., h. 190.
Gambar 5

(Hasil perhitungan dari software Mawaqit)

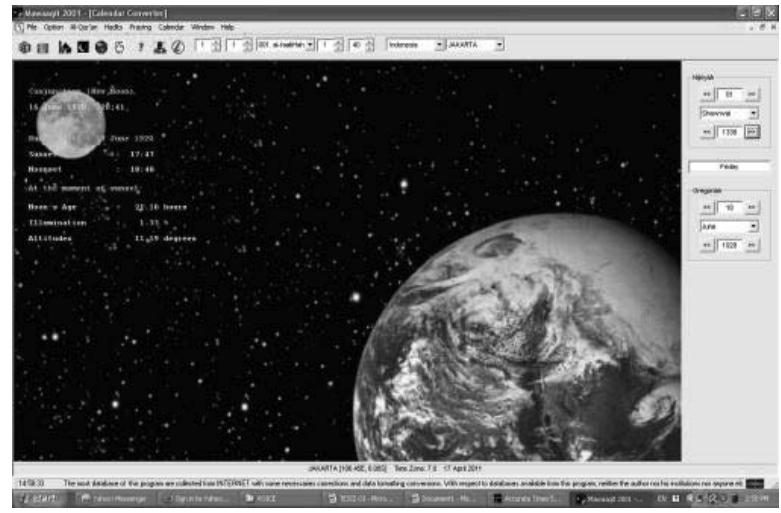

Gambar 6

(Hasil perhitungan dari software Accurate Time)

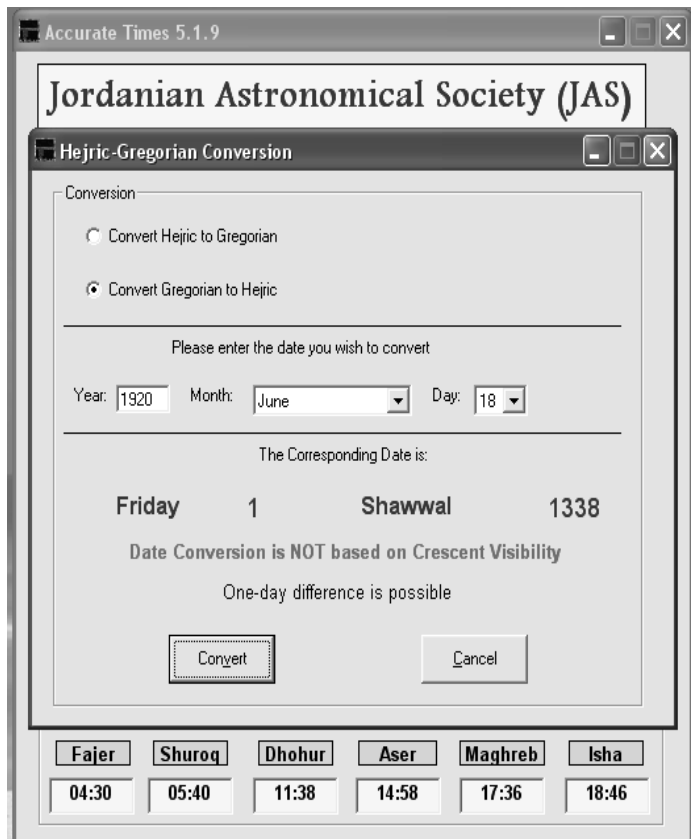

Dari hasil dua software (Mawaqit dan Accurate Time) bahwa pada tahun 1920 hari raya Idul Fitri (1 Syawal) jatuh pada hari Jum'at tanggal 18 Juni / tahun $1338 \mathrm{H}$.

\section{Kesimpulan}

Berdasarkanhasil studimelaluidatakepustakaan, data interview dan beberapa informan yang terkait dalam penelitian ini, maka kesimpulan yang diperoleh dalam penelitian ini adalah: Pertama, KH. Ahmad Dahlan mampu menciptakan sebuah teori dalam menentukan arah kiblat khususnya dalam memakai bola dunia, yang saat itu teknologi belum begitu maju. Dengan bola dunia itu KH. Ahmad Dahlan berijtihad bahwa arah kiblat kota Yogyakarta pada umumnya 
dan Masjid Agung pada khususnya adalah $24^{\circ}$. Dan bila dibandingkan dengan perhitungan software kontemporer saat sekarang arah kiblatnya adalah $25^{\circ} 11^{\prime}$ 0 " atau kurang serong ke kanan $1^{0} 11^{\prime} 0$ " dari kiblat nyata, sedangkan dari perhitungan rumus segitiga bola arah kiblatnya adalah $24^{\circ} 42^{\prime} 21.88^{\prime \prime}$ atau kurang serong ke kanan $0^{\circ} 42^{\prime} 21.88^{\prime \prime}$. Sehingga kesalahan atau deviasi arah kiblat masih bisa ditoleransi.

Dalam pengukuran arah kiblat, KH. Ahmad Dahlan mempunyai pemikiran yang hampir sama dengan Saadoe'ddinDjambek. Hal ini dapatdimaklumi karena KH. Ahmad Dahlan dan Saadoe'ddin Djambek berguru pada Jamil Djambek. Pandangan Syekh Jamil DjambeksangatmempengaruhipemikiranKH.Ahmad Dahlan terutama dalam hal bangunan epistemologi bola dunia. KH. Ahmad Dahlan merupakan tokoh modernis dan reformis dalam bidang ilmu falak, ia

\section{Daftar Pustaka}

Azhari, Susiknan. 2007. Ilmu Falak Perjumpaan Khazanah Islam dan Sains Modern. Yogyakarta: Suara Muhammadiyah.

Azhari, Susiknan.2002.Pembaharuan Pemikiran Hisab di Indonesia studi atas Pemikiran Saadoe'ddin Djambek. Yogyakarta: Pustaka Pelajar.

Azhari, Susiknan. 2008. Ensiklopedi Hisab Rukyat. Yogyakarta: Pustaka Pelajar.

Darban, Ahmad Adaby. 2010. Sejarah Kauman Menguak Identitas Kampung Muhammadiyah. Yogyakarta: Suara Muhammadiyah.

Departemen Agama. 1981. Almanak Hisab Rukyat. Jakarta: Proyek Pembinan Badan Peradilan Agama Islam.

Departemen Agama. 2010, Almanak Hisab Rukyat, Jakarta: Kementerian Agama RI.

Djamaluddin, Thomas. 2010. Hisab Rukyat di Indonesia Serta Permasalahannya. Jakarta: Badan Meteorologi Klimatologi dan Geofisika.

Djamaluddin, Thomas. 2005. Menggagas Fiqih Astronomi. Bandung: Kaki Langit.

Fanani, Muhyar. 2002. Pudarnya Pesona Ilmu Agama. Yogyakarta: Pustaka Pelajar.

Hadikusuma, Djarnawi. 2010. Matahari-Matahari Muhammadiyah. Yogyakarta: Suara Muhammadiyah.

King, David. 1993. Astronomy in the Service of Islam. USA: Variorum.

Madrasah Salafiyah al-Falah Ploso. Tt. Tibyan alMiqat fi ma'rifati al-auqat wa al-Qiblat. Kediri: Ponpes al-Falah. mencoba memadukan antara metode tradisional dan metode modern khususnya dalam penentuan arah kiblat. Oleh karena itu pemikirannya bisa diterima oleh masyarakat, walaupun semula ditolak.

Kedua, Pada mulanya penentuan awal bulan Qamariyah yang dipergunakan oleh KH. Ahmad Dahlan adalah hakiki taqribi mengikuti gurunya K. Dahlan Termas dengan menggunakan Tazkirul Ihwan yang cenderung geosentris. Tetapi setelah berguru dengan Syekh Taher Djalaluddin, KH. Ahmad Dahlan berpindah ke hakiki Tahkiki dengan menggunakan Matla' al-Sa 'id yang cenderung heliosentris. Hal ini amat jelas terlihat pada buku yang ditulis oleh putranya dan sekaligus menjadi murid satu-satunya yang menulis tentang ilmu falak. Corak pemikiran beliau merupakan sintesa-kreatif antara pemikiran hisab tradisional dan modern.

Pasya, Muhammad Kamal. 2009. Muhammadiyah Sebagai Gerakan Isam. Yogyakarta: Pustaka SM.

Pimpinan Pusat Muhammadiyah Majlis Tarjih. 2009. Pedoman Hisab Muhammadiyah. Yogyakarta: Suara Muhammadiyah.

Rachim, Abdurrachim. 1983. Ilmu Falak. Yogyakarta: Liberty.

Ramly, Njamuddin. 2010. Ensiklopedi Tokoh Muhammadiyah Pemikiran dan Kiprah dalam Panggung Sejarah Muhammadiyah. Jakarta: Best Media Utama.

Mulkhan, Mulkhan. 2010. Pesan dan Kisah Kiai Ahmad Dahlan dalam Hikmah Muhammadiyah. Yogyakarta: Suara Muhammadiyah.

Salam, Junus. 2009. KH. Ahmad Dahlan Amal dan Perjuangannya. Tangerang: al-Wasat Publishing House.

Stephenson, W. 2004. Astronomical Instruments and Archives. Seoul: Yonsei University Press.

Setyanto, Hendro. 2002, Rubu'al-Mujayyab,..tt.

Shadiq, Shadiq. 2006. Metode Perhitungan Arah Kiblat. Surabaya: Balai Diklat Kantor Wilayah Departemen Agama.

Sucipto, Hery. 2010, KH. Ahmad Dahlan: Sang Pencerah, Pendidik, dan Pendiri. Jakarta: Best Media Utama.

Syuja', Haji Muhammad. 2009. Islam Berkemajuan (Kisah Perjuangan KH. Ahmad Dahlan dan Muhammadiyah Masa Awal). Tangerang: AlWasath. 
Syukur, Suparman. 2007. Epistemologi Islam Skolastik Pengaruhnya pada Pemikiran Islam Modern. Yogyakarta: Pustaka Pelajar.

Saksono, Tono. 2007. Mengkompromikan Rukyat dan Hisab. Jakarta: Amythas Publicita.

Yusuf, Muhammad Yunan. 2005. Ensiklopedi Muhammadiyah. Jakarta: Raja Grafindo Persada.

\section{Website}

BimasDepag,2007, internetwebsite:http://bimasislam. kemenag.go.id/index.php?option=com content $\&$ view $=$ article $\&$ id $=1124 \&$ catid $=1$ :berita $\&$ Itemi $\mathrm{d}=50$, diakses tanggal 28 November 2010.

Pujangga, 2010 , "Benahi Arah Kiblat", internet website: http://pujangga-lampung.blogspot. com/2010/04/kh-ahmad-dahlan-tokohpembaru-islam-di.html, diakses tanggal 26 November 2010.

Arkanuddin, M., 2007, "KH. Ahmad Dahlan", internet website: http://www.scribd.com/doc/12910954/ Rukyatulhilal-Bw, diakses tanggal 28 November
2010.

Direktorat Jenderal Bimbingan Masyarakat Islam Kementerian Agama Republik Indonesia, "Wardan Diponingrat Kanjeng Yang Ahli Falak", internet website: http://bimasislam. kemenag.go.id/index.php?option $=$ com_content $\&$ view $=$ article $\&$ id $=1135 \&$ catid $=1$ :berita\& Itemi $\mathrm{d}=63$ diakses tanggal 10 Januari 2011).

PKES Interaktif, "Sa'doeddin Djambek Ahli Falak Muhammadiyah", internet website: http://pkesinteraktif.com/edukasi/sosok/1355-saadoeddindjambek-ahli-falak-muhammadiyah-.html, diakses tanggal 10 Januari 2011.

Mas'oed Abidin Abdul Jabbar Blog, "Inyik Djambek (Syekh Muhammad Djamil Djambek), Mata Rantai Gerakan Pembaharuan Pemikiran Islam di Minangkabau", internet website: http:// hmabidin.wordpress.com/2011/02/27/inyikdjambek-syekh-mohamad-djamil-djambekmata-rantai-gerakan-pembaruan-pemikiranislam-di-minangkabau/, diakses tanggal 17 Maret 2011. 